\title{
Comparison of Soil Physical Properties in Conventional and Organic Farming Apple Orchards
}

\author{
Jong-Bae Chung* \\ Division of Life and Environmental Sciences, Daegu University, Gyeongsan 712-714, Korea \\ (Received November 9, 2007, Accepted November 27, 2007)
}

\begin{abstract}
Soil physical properties in organic farming apple orchard were evaluated in relation to conventional farming to better understand the effects of organic farming system on soil quality. Two adjacent apple orchards, matched by soil type, were chosen to ensure the same pedological conditions except management system. Soil samples were collected from middle of two adjacent trees along the tree line at two depths of 5-20 and 20-35 cm in September 2006. Contents of organic matter in organic farming soil were twice as much as those found in soil of conventional farming. The higher level of organic matter in organic farming soil was reflected through a consequent trend in improved soil physical properties. Organic farming produced greater aggregation in $>2 \mathrm{~mm}$ size and increased aggregate stability. Bulk density was lower by $13 \%$ and hence porosity was higher in soils of organic farming as compared with conventional farming. Water holding capacity was significantly greater with organic farming by $>17 \%$ over conventional farming. The capacity of organic farming to improve soil physical properties can be contributed to the regular application of relatively large amount of organic materials and the sustainable ground-cover managements, mulching with compost and cover crop cultivation.
\end{abstract}

Key Words: apple orchard, organic farming, organic matter, soil physical property, soil quality

\section{INTRODUCTION}

Soil is the major source of most of our food production, and its health is essential for sustained food supply for human beings. Quality or productivity of soil can be affected by the type of farming and agricultural practices, and many agricultural activities have negative impacts on soil physical, chemical, and biological properties and can deteriorate soil quality ${ }^{1-3)}$. Industrialized forms of conventional agriculture are dependent on large inputs of inorganic fertilizers and pesticides, and these farming systems tend to be unstable ecosystems in which the potential for maximum yield is inevitably associated with a risk due to ecosystem instability ${ }^{4}$. Soil degradation, including loss of organic matter and biodiversity, acidification, salinization, erosion, destruction of structure, and poor drainage,

*Corresponding author:

Tel: +82-53-850-6755 Fax: +82-53-850-6759

E-mail: jbchung@daegu.ac.kr is mostly a result of continuous use of unsustainable and improper land management systems in conventional agriculture.

Thus, the interest in alternative sustainable agricultural systems has been increased with the world-wide focus on sustainability in human interaction with nature ${ }^{5)}$. The sustainable agriculture system will, over long term, satisfy human food needs and enhance qualities of soil and surrounding natural resources. In organic farming, one of the representative sustainable agricultural systems, soil fertility is often augmented through applications of materials such as compost and manure and by the use of cover crops. Organically managed soils typically differ substantively in fertility as well as a number of soil quality properties when compared to conventionally managed soils ${ }^{6-11)}$. Organic farming systems have been found to have a greater soil organic matter than the conventional agricultural systems ${ }^{12,13)}$, and it has a profound impact on soil quality ${ }^{7,8,14-17)}$. Organic matter encourages granulation, increases water storage, nutrient supply, and soil organism activity, and improves soil 
fertility and productivity. Large amount of decomposing organic residues keeps the organic farming soil in better physical condition, increasing water infiltration and improving its supply to plant. Thus plants are better able to withstand periods of drought; also, less water runoff and erosion is reduced.

Although, the history of sustainable farming is relatively short in our country, it has been rapidly expanding and development of sustainable farming systems necessarily must be based on value judgments for key properties of importance for farming. In this study, the extent of change in soil physical properties resulting from the long-term annual application of compost in organic farming apple orchard was determined and the results were compared with those found in conventional farming apple orchard paired by soil type.

\section{MATERIALS AND METHODS}

\section{Selection of apple orchards}

The conventional and organic based apple orchards selected for this study were located in Yeongchun, Gyeongbuk $\left(36^{\circ} 01^{\prime} \mathrm{N}\right.$ and $\left.128^{\circ} 60^{\prime} \mathrm{E}\right)$. The organic based apple orchard has been managed without using of synthetic fertilizers and pesticides since 1999. The selected apple orchards were two adjacent fields to ensure the same pedological conditions except management system. The soil type in the area is classified as Daegu series (loamy skeletal, nonacid, mesic family of Lithic Eutrudepts). The soil fertility management of the two fields differs markedly but is representative for the conventional and organic farming (Table 1).

Compost used in the organically managed apple orchard was prepared by the farmer using various plant residues and animal manures, and characteristics of the compost were listed in Table 2.

\section{Soil sampling and analysis}

Soil samples were collected from middle of two adjacent trees along the tree line at two depths of 5-20 and 20-35 cm in September 2006. Five sampling sites were selected in both conventional and organic farming apple orchards and two replicated soil samples were collected in each sampling site.

For organic matter determination, soil samples were collected using core sampler, air-dried, and ground to pass a $2 \mathrm{~mm}$ sieve prior to analyses. Total organic $\mathrm{C}$ was determined by dichromate oxidation following Walkley and Black procedure ${ }^{18)}$.

Soil aggregate size distribution was determined by dry sieving method ${ }^{14)}$. Bulk soil samples were collected using core sampler, and air-dried after gently crushing large soil clumps by hand to pass $10 \mathrm{~mm}$ sieve. The prepared soil $(25 \mathrm{~g})$ was sieved through a nest of sieves for $2 \mathrm{~min}$. The nest consisted of 5.0, 2.0, 1.0, and 0.5 $\mathrm{mm}$ mesh sieves. The weight fractions of the samples retained on the sieves were calculated. The mean weight diameter was calculated as the accumulated sum of each fraction times the corresponding mean mesh of the two sieves passing and retaining the fraction ${ }^{19)}$.

The percentage of water stable aggregates $>0.25 \mathrm{~mm}$ index was used as a measure of aggregate stability in water ${ }^{20)}$. Some air-dried soil was transferred to a 2 $\mathrm{mm}$ sieve. All of the soil was passed through the sieve by shaking and gently pressing the soil with thumb. About $5 \mathrm{~g}$ of the sieved soil was placed on a

Table 1. Management practices employed on the conventionally and organically managed apple orchards

\begin{tabular}{|c|c|c|c|}
\hline Farming system & Organic matter input & Chemical input & Tillage method \\
\hline $\begin{array}{l}\text { Conventional } \\
\text { farming }\end{array}$ & $\begin{array}{l}\text { Composted manure application } \\
(10 \mathrm{Mg} / \mathrm{ha}) \text { in December }\end{array}$ & $\begin{array}{l}1 \mathrm{Mg} / \mathrm{ha}(\mathrm{N}-\mathrm{P}-\mathrm{K}=17-21-17) \text { in } \\
\text { February and } 100 \mathrm{~kg} / \mathrm{ha}(\mathrm{N}- \\
\mathrm{P}-\mathrm{K}=17-21-17) \text { in June }\end{array}$ & $\begin{array}{l}\begin{array}{l}\text { Frequent ploughing } \\
\text { deep }\end{array} \\
\text { de.2 } \mathrm{m}\end{array}$ \\
\hline Organic farming & $\begin{array}{l}\text { Fermented compost application } \\
(30 \mathrm{Mg} / \mathrm{ha}) \text { on the surface of the soil } \\
\text { within the drip line in December }\end{array}$ & $\begin{array}{l}\text { Several foliar applications of } \\
\text { nutrients between May and } \\
\text { September }\end{array}$ & $\begin{array}{l}\text { Rye cultivation as cover crop } \\
\text { and soil in drip line mulched } \\
\text { with organic materials }\end{array}$ \\
\hline
\end{tabular}

Table 2. Characteristics of the fermented compost used in the organically managed apple orchard

\begin{tabular}{|c|c|c|c|c|c|c|}
\hline $\mathrm{pH}\left(1: 5 \mathrm{H}_{2} \mathrm{O}\right)$ & $\mathrm{EC}$ & Organic matter & Total N & $\mathrm{NH}_{4}-\mathrm{N}$ & $\mathrm{NO}_{3}-\mathrm{N}$ & Total P \\
\hline & $\mathrm{dS} / \mathrm{m}$ & \multicolumn{2}{|c|}{------- g/kg ------- } & \multicolumn{2}{|c|}{----- $\mathrm{mg} / \mathrm{kg}$----- } & $\mathrm{g} / \mathrm{kg}$ \\
\hline 7.4 & 8.9 & 639 & 33.6 & 659 & 70 & 15.8 \\
\hline
\end{tabular}


$0.25 \mathrm{~mm}$ sieve and saturated by placing the sieve containing the soil on the wet cloth, allowing the soil to wet up slowly for $30 \mathrm{~min}$. Then the soil was wet sieved by moving the sieve up and down in the water through a vertical distance of $4 \mathrm{~cm}$ at the rate of 30 oscillations/min for $3 \mathrm{~min}$. Resistant soil materials on the sieve were quantitatively transferred into a beaker, dried at $60^{\circ} \mathrm{C}$ for $48 \mathrm{~h}$, and then weighed. Correction for the sand fraction accumulated in the sieve was to ensure that only the real aggregates were determined. The corrected total weight of the resistant aggregates $>0.25 \mathrm{~mm}$ was used to calculate the water-stable aggregates $>0.25 \mathrm{~mm}$ index as the percentage ratio of this total weight to that of the initial weight sieved. Higher values indicated better stability.

For bulk density measurement, undisturbed soil core samples (5.0 cm wide and $5.0 \mathrm{~cm}$ height) were collected using metal soil sampling rings (Eijkelkamp, Giesbeek, Netherlands). The soil cores were oven-dried at $105^{\circ} \mathrm{C}$ for $24 \mathrm{~h}$ and weighed. Bulk density was the oven-dried mass divided by the field volume of the core sample. The calculation of bulk density was on a whole soil basis. Soil porosity was calculated from the bulk density with assuming soil particle density to be $2.65 \mathrm{~g} / \mathrm{cm}^{3}$.

For the measurement of water content at field capacity, undisturbed core samples of $5 \mathrm{~cm}$ wide and $5 \mathrm{~cm}$ height were collected using metal soil sampling rings (Eijkelkamp, Giesbeek, Netherlands). The soil cores were slowly saturated for $48 \mathrm{~h}$ and free water was drained for $72 \mathrm{~h}$. Soil water content at field capacity was determined by measuring water retained in the core after free drain. The water retained in the core was determined by the difference in weights before and after drying at $105^{\circ} \mathrm{C}$ for $48 \mathrm{~h}$.

\section{Statistical analysis}

Duncan's multiple range test was used to separate means when the F-value indicated differences at the $P<0.05$ level using SAS program ${ }^{21}$.

\section{RESULTS AND DISCUSSION}

\section{Soil organic matter}

Organic matter contents in the soil of organic management were significantly higher than those subjected to the conventional management (Fig. 1). Average organic matter content in organic farming soil was twice as much as that found in conventional farming soil in both depths. The differences in organic matter content between two soil depths were not significant in both organic and conventional farming systems.

The significantly higher organic matter content in organic farming orchard soil could be due to the higher rate of regular input of organic material. Although several years of contrasting soil management are not sufficient to produce a consistent difference in organic matter content, the steady use of organic materials on organic farms is considered important in maintaining the level of soil organic matter ${ }^{9)}$. Depending on soil type, climate, management, and the capacity of a soil to store organic matter, organic $\mathrm{C}$ levels may increase linearly with the amount of organic matter input ${ }^{8)}$. And the use of organic materials have been well known to maintain soil organic matter at higher levels than inorganic fertilization ${ }^{13)}$. Soil C increased 27.9, 15.1, and $8.6 \%$ in the organic animal, organic legume, and conventional systems, respectively, after 22 years of separate management ${ }^{22}$. Also, relatively greater content of organic matter was found in organic farming orchard soils in Korea, irrespective of growing crops ${ }^{23}$.

Conservation tillage is often a beneficial method for reducing organic matter losses in agricultural soils. In general, trapping $C$ in aggregates can slow mineralization and result in a net gain in soil $\mathrm{C}^{3,24)}$. The higher organic matter in the organic farming apple orchard soil could be due in part to the different ground-cover management between conventional and organic farming. In the organic farming apple orchard, no tillage system was adopted and soil surface was covered by mulching with organic materials and cover crop cultivation.

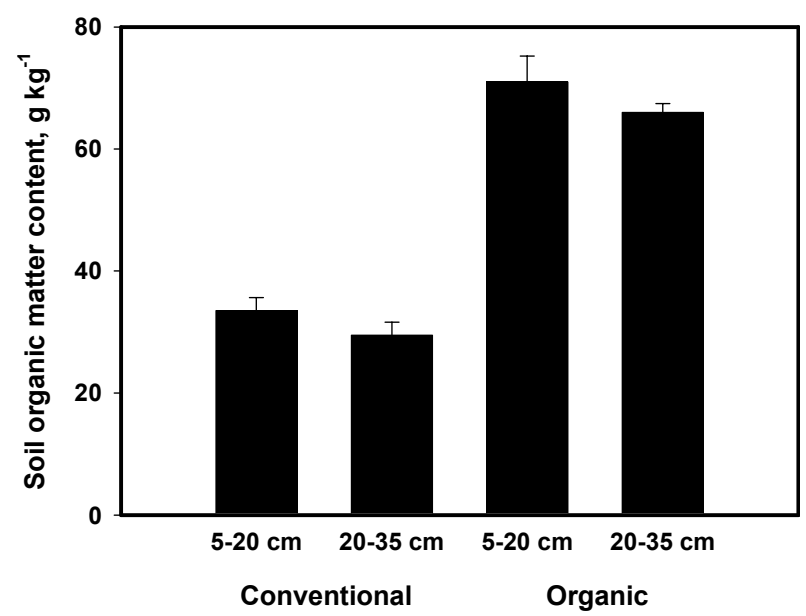

Fig. 1. Organic matter content in the soils of conventional and organic farming apple orchards. 
Organic matter is one of the most important soil components, and it plays a major role in improving various soil properties. Soil physical properties, such as aggregate stability and porosity, are directly influenced by soil organic matter content. This is then observed as less crusting, better water infiltration and drainage, reduced compaction and erodibility, and an improved water holding capacity. Large amounts of organic matter are also expected to increase soil biodiversity and activities ${ }^{11,25)}$, and these are particularly helpful in further improving soil physical properties.

\section{Soil aggregate size distribution and stability}

Stable soil aggregates are critical to erosion resistance, water availability, and root growth. Stable aggregates mainly result from decomposition of organic materials due to the soil biota producing materials that bind particles together. Increased bonding of soil mineral particles would be reflected in the cumulative aggregate size distribution, wet aggregate stability, and amount of dispersible clay.

The visual evaluation showed that the soils of organic farming orchard had darker color and more aggregated features than those of conventional farming orchard (Fig. 2). As shown in Table 3 , in organic farming soil the fraction of aggregates $>2 \mathrm{~mm}$ was significantly greater and the fraction of aggregates $<1 \mathrm{~mm}$ was much less in both soil depths in comparison to the soil of conventional farming. Although it is known that the organic matter effect on aggregate size in a given size range depends on soil texture ${ }^{14)}$, the higher rate of organic matter application in organic farming apple orchard consistently increased the diameter of soil aggregates.

The mean weight diameter was calculated in an attempt to integrate the effect of organic matter over all size ranges of aggregates (Table 3). Mean weight diameter for the organic farming soil was significantly higher than that found in the soil of conventional farming orchard. This increase of mean weight diameter was due mainly to the relatively large increases in the aggregates $>5 \mathrm{~mm}$. These results found in this study confirm the reported effect of organic matter on mean aggregate size ${ }^{15,26)}$.

The improved soil aggregation in organic farming apple orchard could be also due to the difference in ground-cover management system between the two farming systems. No tillage system adopted in organic farming could contribute in development of soil aggregation. It has been reported that the increase in mean weight diameter in the conservation tillage treatments, especially in the 0 to $5 \mathrm{~cm}$ depth, was probably related

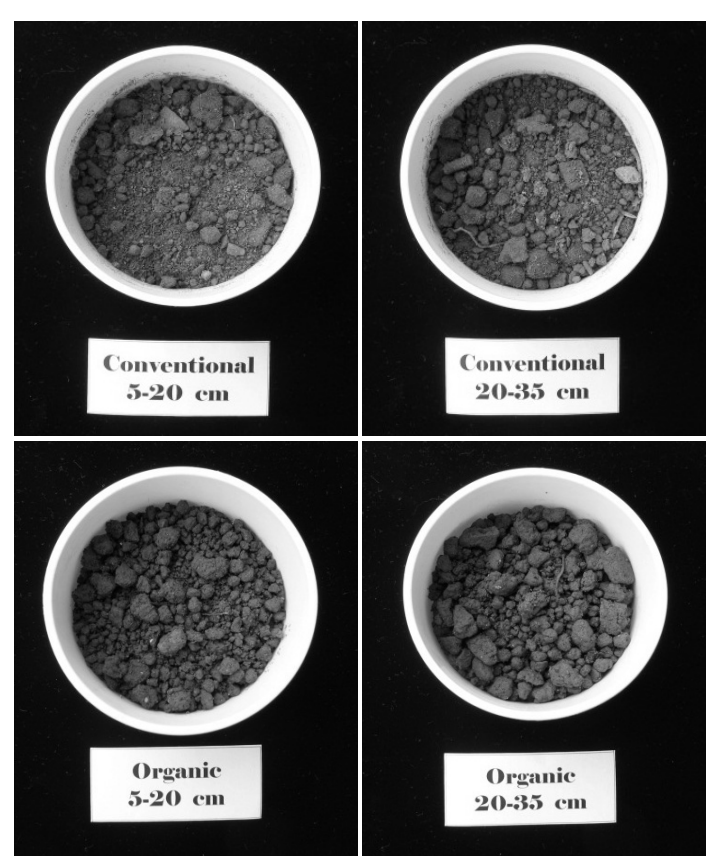

Fig. 2. Features of aggregation in conventional and organic farming apple orchard soils.

Table 3. Effect of conventional and organic farming on soil aggregate size distribution in apple orchards

\begin{tabular}{ccccccc}
\hline Farming system and soil depth & $>5 \mathrm{~mm}$ & $5-2 \mathrm{~mm}$ & $2-1 \mathrm{~mm}$ & $1-0.5 \mathrm{~mm}$ & $<0.5 \mathrm{~mm}$ & Mean weight diameter \\
\hline & $-17.6 \pm 0.9$ & $29.1 \pm 2.0$ & $17.7 \pm 0.3$ & $16.7 \pm 0.6$ & $18.9 \pm 1.5$ & $2.78 \pm 0.21 \mathrm{~b}^{\dagger}$ \\
Conventional & & & & \\
$5-20 \mathrm{~cm}$ & $18.8 \pm 0.9$ & $29.8 \pm 1.7$ & $20.9 \pm 0.5$ & $15.0 \pm 0.9$ & $15.6 \pm 0.4$ & $2.93 \pm 0.09 \mathrm{~b}$ \\
$20-35 \mathrm{~cm}$ & & & & & \\
Organic & $47.5 \pm 1.0$ & $30.9 \pm 1.2$ & $12.7 \pm 2.1$ & $5.8 \pm 0.6$ & $3.1 \pm 1.3$ & $4.89 \pm 0.42 \mathrm{a}$ \\
$5-20 \mathrm{~cm}$ & $48.6 \pm 4.7$ & $34.4 \pm 1.0$ & $9.5 \pm 0.9$ & $3.9 \pm 0.4$ & $3.6 \pm 2.2$ & $5.03 \pm 0.35 \mathrm{a}$ \\
$20-35 \mathrm{~cm}$ & & &
\end{tabular}

\footnotetext{
${ }^{\dagger}$ Means within a column followed by the same letter are not significantly different at $P<0.05$.
} 
to increased soil organic matter in those treatments ${ }^{24)}$. Also the pattern of a greater proportion of small aggregates and lower proportion of large aggregates was found in intensive tillage system ${ }^{3)}$.

Wet aggregate stability, the percentage of water stable aggregates $>0.25 \mathrm{~mm}$, in 5-20 cm depth soil was significantly higher in organic farming apple orchard as compared with that found in conventional farming (Table 4). Generally, dispersible clay decreases and wet aggregate stability increases in soils receiving organic matter $^{14,15)}$. Soil aggregate stability was found to be improved and maintained with time more by hydrophobic components of organic matter ${ }^{20)}$.

\section{Soil bulk density and porosity}

Soil bulk density is attributable to the relative proportion and specific gravity of solid organic and inorganic particles and to the porosity of the soil. In general, the bulk density of a soil increases with profile depth, due to changes in organic matter content, clay content, and compaction.

As shown in Fig. 3 and 4, organic farming resulted in lower bulk densities and hence higher porosities in both soil depths as compared with conventional farming. Bulk density was higher at $20-35 \mathrm{~cm}$ depth as compared with 5-20 cm depth in both farming systems, but the differences were not significant. Average bulk densities of organic farming apple orchard soils were within the range of ideal value $\left(<1.40 \mathrm{~g} / \mathrm{cm}^{3}\right)$ for plant root growth ${ }^{27}$. Other researchers also reported that soil bulk density was significantly lower on four of the five organic farms as compared with conventional farms ${ }^{7}$.

With few exceptions, organic matter decreases the bulk density of soil ${ }^{15,16}$, and this effect can occur either directly by diluting the soil with a less dense material, or indirectly through greater aggregate stability. Indirect effects are more important and organic matter organizes soil mineral particles into structural

Table 4. Effect of conventional and organic farming on soil aggregate stability (percent of water stable aggregate $>0.25 \mathrm{~mm}$ ) in apple orchards

\begin{tabular}{cc}
\hline $\begin{array}{c}\text { Farming system and soil } \\
\text { depth }\end{array}$ & $\begin{array}{c}\% \text { of soil aggregate }>0.25 \\
\mathrm{~mm}\end{array}$ \\
\hline $\begin{array}{c}\text { Conventional, } 5-20 \mathrm{~cm} \\
\text { Organic, } 5-20 \mathrm{~cm}\end{array}$ & $65.5 \pm 6.6 \mathrm{a}^{\dagger}$ \\
$42.7 \pm 4.8 \mathrm{~b}$
\end{tabular}

\footnotetext{
${ }^{\dagger}$ Means within a column followed by the same letter are not significantly different at $P<0.05$.
}

units that improve porosity, thereby decreasing bulk density.

The lower bulk density and higher porosity in the organic farming apple orchard soil can be also contributed to the ground-cover management of mulching and no tillage. Ground-cover management system can also affect soil bulk density and porosity. Bulk density is generally lower and soil porosity greater under mulching system than other ground-cover management systems where surface vegetation is controlled by herbicides, periodic mechanical cultivation, or routine mowing ${ }^{28)}$.

However, in a number of investigations, soil bulk densities of the organic and conventional farms were not significantly different in short-term or even in longterm trials. Those results can be due to the soil com-

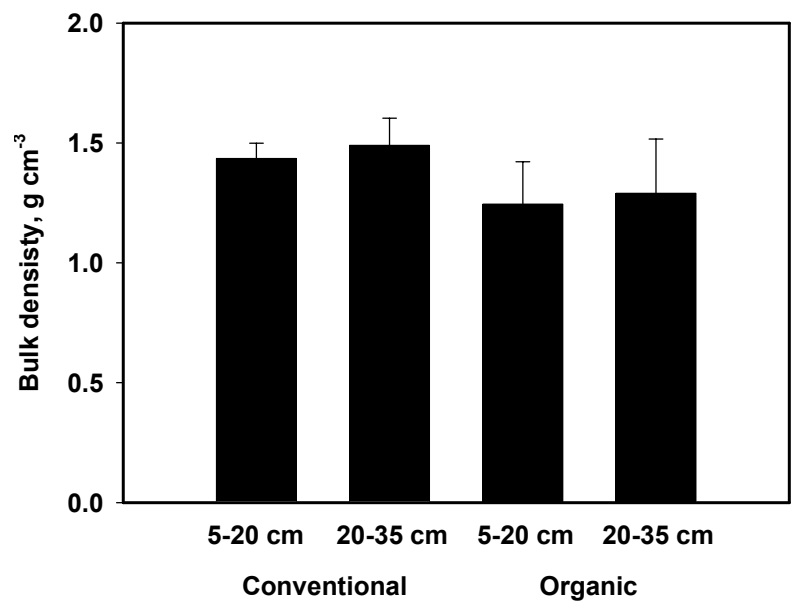

Fig. 3. Effect of conventional and organic management on bulk density of apple orchard soils.

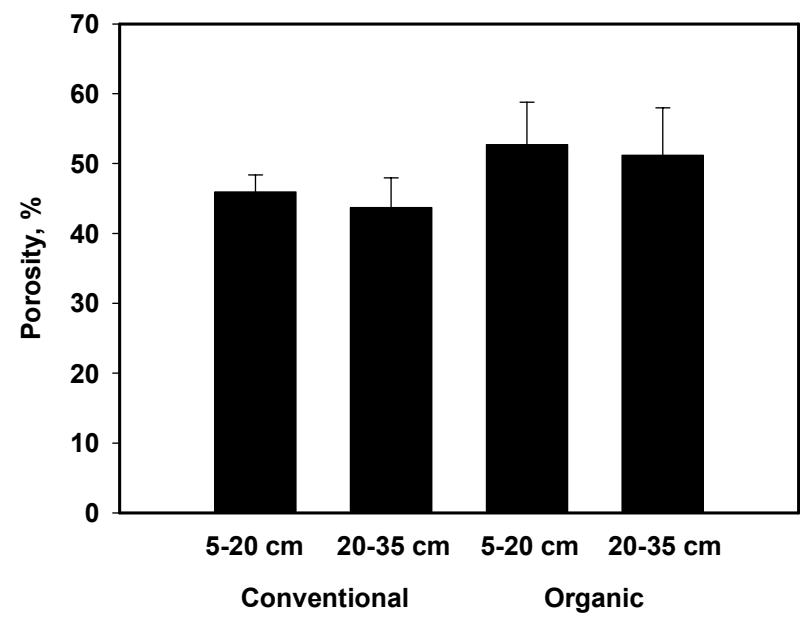

Fig. 4. Effect of conventional and organic management on porosity of apple orchard soils. 
paction by wheel traffics, intensive tillage, and other ground activities. The negative effects from extensive traffic are able to overshadow the positive effect of organic manuring and diversified crop rotation on soil properties and functions ${ }^{16}$.

\section{Soil water retention}

Moisture holding capacity can be an important determinant in crop productivity, especially in hot climates. Water content at field capacity was relatively higher in both soil depths of organic farming apple orchard as compared with conventional farming orchard (Fig. 5). Improvement of soil moisture holding capacity is commonly observed in organic farming systems. In Nebraska and North Dakota, as compared with the conventional farms, available water holding capacity was significantly higher on most of the organic farms investigated $^{7,14}$. The three times higher organic matter in organic farms was contributed to the less frequent tillage and less erosion, and it resulted in the higher available water holding capacity as compared with the conventional farms. A greater water holding capacity was found when reduced tillage was compared with conventional plow tillage ${ }^{24)}$. And such result suggests that the increase in organic matter with conservation tillage produces a system that holds significantly more water in the plant available water range and beyond.

The increased water holding capacity in organic farming soils could be due not only to the higher organic matter content but also to its effect on aggregation and aggregate size distribution. Organic matter has a high water holding capacity but the water

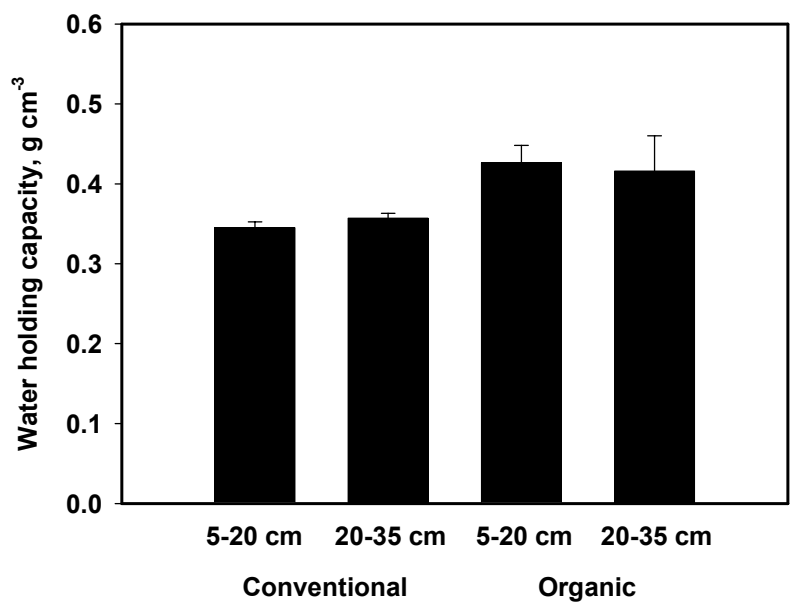

Fig. 5. Effect of conventional and organic management on the water holding capacity of apple orchard soils. retained is not easily released even at high tensions. The observed increase of available water holding capacity in high organic matter soil is probably due to the improved aggregation and aggregate size distribution ${ }^{14}$.

\section{CONCLUSIONS}

Organic farming had a greater capacity to improve physical properties of apple orchard soil as compared with conventional farming. It would be due mainly to the application of organic amendments and more sustainable ground-cover management system.

Due to the regular application of relatively large amount of organic materials, level of organic matter in organic farming soil was twice as much as that found in soil of conventional farming. Sustainable ground-cover managements, mulching with compost and cover crop cultivation, could be also helpful in increasing the level of organic matter by restricting its degradation. The high level of organic matter in organic farming soil was reflected through a consequent trend in improved size distribution and stability of aggregates, lower bulk density and higher porosity, and higher water holding capacity.

The improved structural stability of soil is expected to increase infiltration rate and hydraulic conductivity under organic farming, and these can further resulted in creation of optimal conditions for plant growth and conservation of soil and water resources.

\section{REFERENCES}

1. Pacini, C. A., Wossink, A., Gisen, G., Vazzanna, C. and Huine, R. (2003) Evaluation of sustainability of organic, integrated and conventional farming systems: A farm and field-scale analysis, Agric. Ecosyst. Environ. 95, 273-288.

2. Bronick, C. J. and Lal, R. (2005) Soil structure and management: A review, Geoderma 124, 3-22.

3. Mikha, M. M. and Rice, C. W. (2004) Tillage and manure effects on soil and aggregate associated carbon and nitrogen, Soil Sci. Soc. Am. J. 68, 809-816.

4. Vogtmann, H. (1984) Organic farming practices and research in Europe, In Kral, D. M. et al. (ed.) Organic farming: Current technology and its role in a sustainable agriculture, ASA Special Publication No. 46, American Society of Agronomy, Madison, WI, USA, p. 19-36. 
5. Hatfield, J. L. and Karlen, D. L. (1994) Sustainable agriculture system, Lewis Publishes, Boca Raton, FL, USA.

6. Gerhardt, R. A. (1997) A comparative analysis of the effects of organic and conventional farming systems on soil structure, Biol. Agric. Hort. 14, 139-157.

7. Liebig, M. A. and Doran, J. W. (1999) Impact of organic production practices on soil quality indicators, J. Environ. Qual. 28, 1601-1609.

8. Carter, M. R. (2002) Soil quality for sustainable land management: Organic matter and aggregation interactions that maintain soil functions, Agron. J. 94, 38-47.

9. Marinari, S., Mancinelli, R., Campiglia, E. and Grego, S. (2006) Chemical and biological indicators of soil quality in organic and conventional farming systems in Central Italy, Ecol. Indicators 6, 701-711.

10. Melero, S., Porras, J. C. R., Herencia, J. F. and Madejon, E. (2006) Chemical and biochemical properties in a silty loam soil under conventional and organic management, Soil Tillage Res. 90, 162-170.

11. Tejada, M., Hernandez, M. T. and Garcia, C. (2006) Application of two organic amendments on soil restoration: Effects on the soil biological properties, J. Environ. Qual. 35, 1010-1017.

12. Martini, E. A., Buyer, J. S., Bryant, D. C., Hartz, T. K. and Denison, R. F. (2004) Yield increases during the organic transition: improving soil quality or increasing experience? Field Crop. Res. 86, 255-266.

13. Marriott, E. E. and Wander, M. M. (2006) Total and labile soil inorganic matter in organic and conventional farming systems, Soil Sci. Soc. Am. J. 70, 950-959.

14. Darwish, O. H., Persaud, N. and Martens, D. C. (1995) Effect of long-term application of animal manure on physical properties of three soils, Plant Soil 176, 289-295.

15. Barzegar, A. R., Yousefi, A. and Daryashenas, A. (2002) The effect of addition of different amounts and types of organic materials on soil physical properties and yield of wheat, Plant Soil 247, 295-301.

16. Schjønning, P., Elmholt, S., Munkholm, L. J. and Debosz, K. (2002) Soil quality aspects of humid sandy loams as influenced by organic and conventional long-term management, Agric. Ecosyst. Environ. 88, 195-214.

17. Zaller, J. G. and Kopke, U. (2004) Effects of traditional and biodynamic farmyard manure amend- ment on yields, soil chemical, biochemical and biological properties in a long-term experiment, Biol. Fertil. Soils 40, 222-229.

18. Nelson, D. W. and Sommers, L. E. (1982) Total carbon, organic carbon, and organic matter, In Page, A. L. et al. (ed.) Methods of soil analysis, Part 2: Chemical and microbiological properties, Soil Science Society of America, Madison, WI, USA, p. 539-579.

19. Haynes, R. J. (1993) Effect of sample pretreatment on aggregate stability measured by wet sieving or turbidimetry on soils of different cropping history, J. Soil Sci. 44, 261-270.

20. Piccolo, A. and Mbagwu, J. S. C. (1999) Role of hydrophobic components of soil organic matter in soil aggregate stability, Soil Sci. Soc. Am. J. 63, 1801-1810.

21. SAS Institute. (1995) SAS/EIs software reference (2nd ed.) SAS Institute, Cary, NC, USA.

22. Pimentel, D., Hepperly, P., Hanson, J., Douds, D. and Seidel, R. (2005) Environmental, energetic, and economic comparisons of organic and conventional farming systems, BioScience 55, 573-582.

23. Lee, Y. J., Choi, D. H., Kim, S. H., Lee, S. M., Lee, Y. H., Lee, B. M. and Kim, T. W. (2004) Longterm changes in soil chemical properties in organic arable farming systems in Korea, Korean J. Soil Sci. Fert. 37, 228-234.

24. Zibilske, L. M. and Bradford, J. M. (2007) Soil aggregation, aggregate carbon and nitrogen, and moisture retention induced by conservation tillage, Soil Sci. Soc. Am. J. 71, 793-802.

25. Mader, P., Fliebach, A., Dubois, D., Gunst, L., Fried, P. and Niggli, U. (2002) Soil fertility and biodiversity in organic farming, Science 296, 1694-1697.

26. Oades, J. M. (1984) Soil organic matter and structural stability mechanisms and implications for management, Plant Soil 76, 319-337.

27. Arshad, M. A., Lowery, B. and Grossman, B. (1996) Physical tests for monitoring soil quality, In Doran, J. W. and Jones, A. J. (ed.) Methods for assessing soil quality, SSSA Special Publication No. 49, Soil Science Society of America, Madison, WI, USA, p. 123-142.

28. Oliveira, M. T. and Merwin, I. A. (2001) Soil physical conditions in a New York orchard after eight years under different ground-cover management systems, Plant Soil 234, 233-237. 